\title{
ANALISIS PERMINTAAN DAN PENAWARAN LULUSAN SMK DALAM PEMENUHAN PASAR TENAGA KERJA
}

\section{Novrian Satria Perdana}

Pusat Penelitian Kebijakan Pendidikan dan Kebudayaan Jakarta

E-mail: novrian1711@gmail.com

\begin{tabular}{|c|c|}
\hline Info Artikel & Abstract \\
\hline $\begin{array}{l}\text { Sejarah Artikel: } \\
\text { Diterima 25 Januari } 2019 \\
\text { Direvisi } 27 \text { Mei } 2019 \\
\text { Disetujui } 31 \text { Mei } 2019\end{array}$ & $\begin{array}{l}\text { The objectives of this study are (1) to analyze DUDI demand on the competence of } \\
\text { vocational graduates in an effort to achieve a balance of the labor market, and (2) analyze } \\
\text { the supply of vocational graduates needed by DUDI in an effort to achieve a balance of the } \\
\text { labor market. In this study using qualitative approaches primary data analysis methods. } \\
\text { This research was conducted in Central Java Province in 2018. The results of this study } \\
\text { are: (1) the qualifications of the workforce needed for DUDI in the middle to upper scale }\end{array}$ \\
\hline $\begin{array}{l}\text { Keywords: } \\
\text { Labor, Vocational School, } \\
\text { Graduates }\end{array}$ & $\begin{array}{l}\text { are primarly having a certificate of competence, having II and forelgn language skills, } \\
\text { and having experience working in the field the same for } 1 \text { year, and (2) the competencies of } \\
\text { vocational graduates produced have been sought to adjust DUDI's needs, but there are } \\
\text { limitations in the ability of vocational graduates because of the lack of facilities and } \\
\text { infrastructure in schools and the limited ability of educators. }\end{array}$ \\
\hline
\end{tabular}

\begin{abstract}
Abstrak
Tujuan dari penelitian ini adalah (1) menganalisis permintaan (demand) DUDI terhadap kompetensi lulusan SMK dalam upaya mencapai keseimbangan pasar tenaga kerja, dan (2) menganalisis penyediaan (supply) lulusan SMK yang dibutuhkan DUDI dalam upaya mencapai keseimbangan pasar tenaga kerja. Dalam penelitian ini menggunakan pendekatan kualitatif dengan metode analisis primer. Penelitian ini dilakukan di Provinsi Jawa Tengah tahun 2018. Hasil penelitian ini yaitu: (1) kualifikasi tenaga kerja yang dibutuhkan DUDI skala menengah ke atas yang utama adalah telah memiliki sertifikat kompetensi, memiliki kemampuan IT dan bahasa asing, dan telah memiliki pengalaman bekerja pada bidang yang sama selama 1 tahun, dan (2) Kompetensi lulusan SMK yang dihasilkan telah diupayakan menyesuaikan kebutuhan DUDI, namun adanya keterbatasan kemampuan lulusan SMK karena minimnya sarana dan prasarana yang ada di sekolah dan keterbatasan kemampuan tenaga pendidik.
\end{abstract}




\section{Perdana, Novrian Satria \\ OPTIMALISASI KESEIMBANGAN PASAR TENAGA KERJA LULUSAN SMK ... \\ REFLEKSI EDUKATIKA : Jurnal Ilmiah Kependidikan, Volume 9, Nomor 2, Juni 2019, hlm 172-181}

\section{PENDAHULUAN}

Sumber Daya Manusia (SDM) merupakan aset utama dalam membangun kemajuan suatu bangsa. Ketersediaan sumber daya alam (natural resources) yang melimpah dan adanya sumber daya modal serta teknologi yang semakin canggih, tidak akan mempunyai kontribusi yang bernilai tambah, tanpa didukung oleh adanya sumber daya manusia (human resources) yang berkualitas. Dengan jumlah SDM yang besar terutama yang memiliki kompetensi dan memiliki produktivitas tinggi, maka negara dapat mencapai pertumbuhan optimal dan juga memiliki nilai competitiveness lebih dibanding negara lainnya.

Berkaitan dengan daya saing Indonesia, berdasarkan data yang bersumber dari World Economic Forum (2018) pada tahun 2018 Global Competitiveness Index Indonesia berada di peringkat 45 jauh di bawah sesama negara ASEAN, yaitu Singapura peringkat 7, Malaysia peringkat 21 dan Thailand peringkat 28. Khusus untuk pilar ke-6 tentang skills, Indonesia berada di peringkat 62 , juga masih kalah dibandingkan dengan Negara Singapura (20), dan Malaysia (24), namun sudah unggul dengan Thailand (66). Kondisi ini menunjukkan bahwa berbagai komoditi Indonesia kurang berdaya saing di pasar global termasuk SDMnya. Daya saing merupakan sekumpulan intuisi, kebijakan, dan faktor yang menentukan tingkat produktivitas dari suatu negara.

Dunia pendidikan merupakan sumber utama dalam penyediaan tenaga kerja (SDM) yang kompeten di pasar tenaga kerja. Namun masih ada gap antara kebutuhan SDM di industri dengan SDM yang dihasilkan oleh lembaga pendidikan. Ancaman lain adalah akan ada serbuan tenaga kerja asing ke negara ini jika semua pintu globalisasi telah dibuka. Implikasinya dalam pengembangan SDM adalah walaupun hanya untuk memenuhi kebutuhan lokal namun kualitas tetap dituntut untuk memenuhi standar global agar tetap mampu bersaing dan tidak tersisih di negeri sendiri.

Kritik tajam yang selalu dilontarkan oleh para pengguna lulusan lembaga pendidikan adalah kompetensi lulusan yang dihasilkan oleh lembaga pendidikan masih jauh dari standar kompetensi yang ditetapkan oleh industri. Tenaga kerja yang qualified dan certified sulit diperoleh oleh sebagian besar industri. Sehingga seringkali kalangan industri masih membutuhkan biaya besar dan mengalokasikan waktu yang cukup lama untuk program training guna menyetarakan kompetensi tenaga kerja baru (fresh graduated) dengan sistem kerja yang ada di industri. Untuk menjembatani gap antara kebutuhan SDM yang profesional di industri dengan output lembaga pendidikan, dibutuhkan sinergi kekuatan antara dunia pendidikan dan dunia industri. Peran membangun SDM ini menjadi tanggung jawab bersama antara pemerintah, industri, masyarakat, dan lembaga pendidikan. Dalam mencetak SDM yang profesional lembaga pendidikan harus dipacu oleh kalangan industri demikian pula untuk memenangkan persaingan, industri harus dipacu oleh dunia pendidikan. Link and match dunia pendidikan dan dunia industri haruslah semakin diwujudnyatakan. Untuk itu sangat diperlukan kerjasama (partnership) yang baik, saling menguntungkan dan berkelanjutan antara dunia industri dan pendidikan.

Saat ini, kebutuhan Dunia Usaha dan Dunia Industri (DU/DI) akan tenaga kerja yang kompeten masih belum dapat dipenuhi oleh ketersediaan (supply) tenaga kerja yang ada, sementara di sisi lain mayoritas angkatan kerja yang ada masih berpendidikan rendah yaitu 60,2 persen hanya menamatkan pendidikan tingkat SMP atau lebih rendah. Dengan demikian hanya 39,8 persen dari angkatan kerja yang memiliki tingkat pendidikan SMA/SMK, akademi/diploma, ataupun lulusan perguruan tinggi.

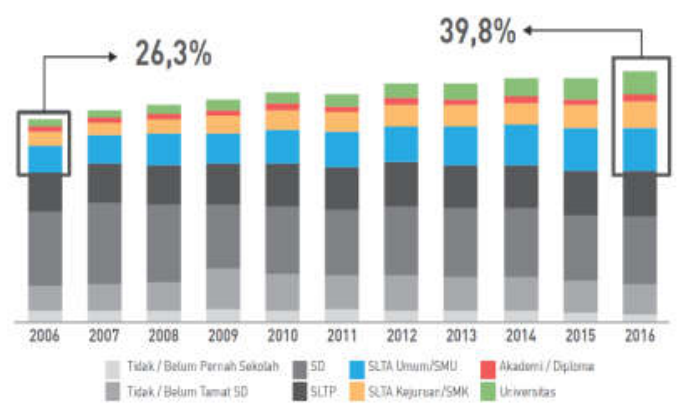

Gambar 1. Angkatan Kerja Berdasarkan Tingkat Pendidikan di Indonesia Periode 2006-2016

Pada tahun 2018, tercatat bahwa tingkat pendidikan angkatan kerjapun masih didominasi oleh angkatan kerja dengan pendidikan tamatan SD. Berdasarkan data yang bersumber dari BPS (2018) yang tertera pada gambar 2 di bawah ini, 


\section{Perdana, Novrian Satria \\ OPTIMALISASI KESEIMBANGAN PASAR TENAGA KERJA LULUSAN SMK ... \\ REFLEKSI EDUKATIKA : Jurnal Ilmiah Kependidikan, Volume 9, Nomor 2, Juni 2019, hlm 172-181}

menyimpulkan bahwa latar belakang pendidikan pekerja di Indonesia masih di dominasi oleh lulusan SD ke bawah, yaitu sebanyak 16.923.691 pekerja yang terbagi menjadi buruh/karyawan/ pegawai sebesar 20,28 persen, pekerja bebas di pertanian sebesar 76,55 persen dan pekerja bebas di non pertanian sebesar 56,73 persen. Banyaknya lulusan SD yang tidak diikuti dengan jumlah lulusan ke jenjang berikutnya dikhawatirkan dapat menghambat produktifitas pekerja akibat rendahnya tingkat pendidikan/ pengetahuan yang mereka peroleh, karena pada dasarnya lulusan jenjang pendidikan dasar (SD) masih belum memiliki keterampilan kerja yang berkualitas sehingga dikhawatirkan akan menganggur atau bila bekerja dikhawatirkan akan kalah bersaing dengan pekerja dari negara lain dalam era perdagangan bebas.

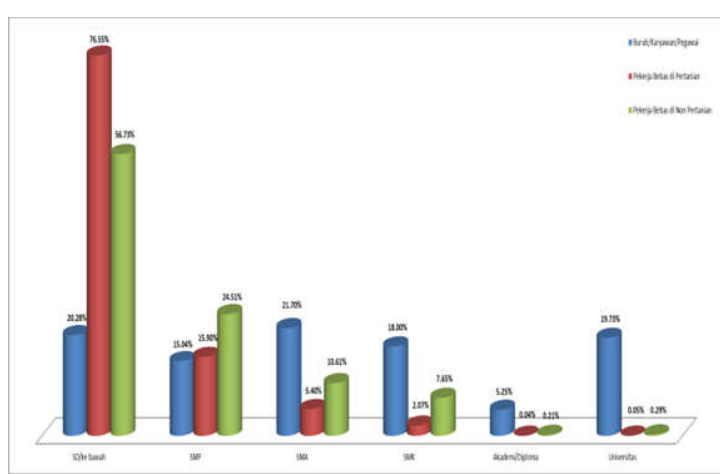

Sumber: BPS, 2018

Gambar 2. Angkatan Kerja Indonesia Menurut Tingkat Pendidikan

Hal yang sebaliknya terjadi pada tingkat pengangguran di Indonesia, yang justru didominasi oleh lulusan dari tingkat pendidikan yang lebih tinggi (SMA, SMK, Akademi/Diploma, dan Universitas), yang seharusnya memiliki kompetensi yang cukup tinggi pula, sebagaimana tampak pada gambar berikut.

Apabila melihat dari kebutuhan akan tenaga kerja oleh industri di Indonesia, tingkat pendidikan minimal yang dibutuhkan adalah setingkat SMA atau SMK untuk jabatan setingkat dengan operator. Dimana dianggap memiliki keterampilan atau kompetensi khusus yang dapat menjadi nilai tambah, seseorang dituntut untuk memiliki sertifikat kompetensi baik melalui pelatihan ataupun sertifikasi. Namun rendahnya tingkat angkatan kerja yang memperoleh pelatihan dan sertifikat kompetensi merupakan salah satu indikator rendahnya serta tidak sesuainya kompetensi yang dimiliki oleh para pekerja di Indonesia (Kemenko Perekonomian RI, 2017). Dengan kata lain, belum ada keselarasan antara kompetensi yang diajarkan di SMK dengan kebutuhan DU/DI.

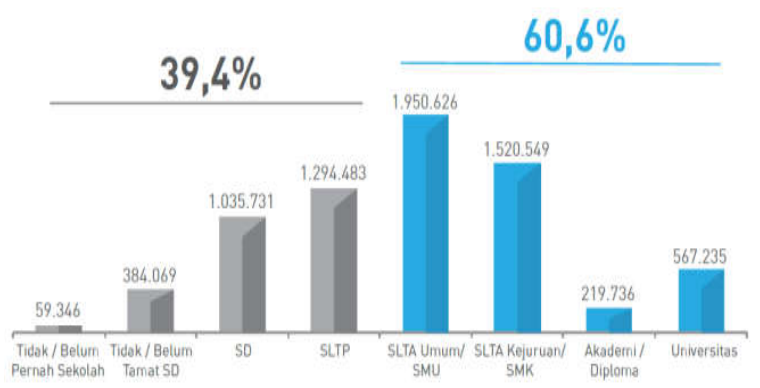

Gambar 3. Tingkat Pengangguran Menurut Tingkat Pendidikan Tahun 2016

Selain menghadapi masalah kualitas SDM, Indonesia juga dihadapkan pada era revolusi industri 4.0. Revolusi 4.0 ini mengalami puncaknya yang ditandai dengan lahirnya teknologi digital yang berdampak masif terhadap hidup manusia di seluruh dunia. Revolusi ini telah mendorong sistem otomatisasi di dalam semua proses aktivitas. Teknologi internet yang semakin masif tidak hanya menghubungkan jutaan manusia di seluruh dunia tetapi juga telah menjadi basis bagi transaksi perdagangan dan transportasi secara online.

The McKinsey Global Institute (2017) memperkirakan bahwa sebesar $50 \%$ dari lapangan pekerjaan berpotensi untuk diotomatisasi dengan mengadaptasi teknologi baru. Meskipun kurang dari 5\% pekerjaan dapat sepenuhnya otomatis, namun $60 \%$ dapat memiliki 30\% atau lebih dari kegiatan mereka dapat diotomatisasi secara teknis. Aktivitas seperti mengumpulkan dan memproses data, aktivitas fisik dan mengoperasikan mesin memiliki potensi teknis tertinggi untuk dilakukan otomatisasi. Di sisi lain, kegiatan yang melibatkan interaksi dengan pemangku kepentingan, menerapkan keahlian untuk pengambilan keputusan, perencanaan, dan tugastugas kreatif, atau mengelola dan mengembangkan orang kurang rentan untuk berpotensi dilakukan otomatisasi. 

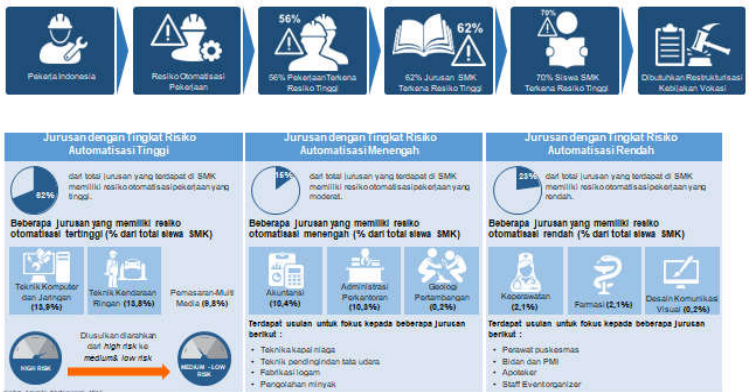

Sumber: Direktorat PSMK, 2017

Gambar 4. Automatisasi Akibat Perkembangan Teknologi

Tantangan dunia kerja di era revolusi industri 4.0 adalah integrasi pemanfaatan internet dengan lini produksi yang memanfaatkan kecanggihan teknologi dan informasi. Karakteristik revolusi industri 4.0 ini meliputi digitalisasi, optimalisasi dan kustomisasi produksi, otomasi dan adapsi, interaksi antara mesin-manusia, nilai tambah jasa dan bisnis, automatic data exchange and communication, dan penggunaan teknologi internet. Tantangan tersebut, harus dapat diantisipasi melalui transformasi pasar kerja Indonesia dengan mempertimbangkan perubahan iklim bisnis dan industri, perubahan jabatan structural yang terjadi pada organisasi dan kebutuhan ketrampilan. Salah satu faktor yang penting adalah keterampilan dan kompetensi yang harus tetap secara konsisten perlu ditingkatkan sesuai kebutuhan pasar kerja yang semakin berkembang pesat. Oleh karena itu, dunia pendidikan dan dunia industri harus dapat mengembangkan industrial transformation strategy. Salah satunya dengan mempertimbangkan perkembangan sektor ketenagakerjaan karena transformasi industri akan berhasil dengan adanya tenaga kerja yang kompeten. Dalam menghadapi revolusi industri 4.0, sedikitnya ada tiga hal yang yang perlu diperhatikan semua pihak. Pertama adalah kualitas, yaitu upaya menghasilkan SDM yang berkualitas agar sesuai dengan kebutuhan pasar kerja yang berbasis teknologi digital. Kedua, adalah masalah kuantitas, yaitu menghasilkan jumlah SDM yang berkualitas, kompeten dan sesuai kebutuhan industri. Ketiga, adalah masalah distribusi SDM berkualitas yang masih belum merata.

Salah satu upaya untuk menghasilkan SDM berkualitas dalam bidang aplikasi keilmuan tertentu dengan keterampilan khusus yang sangat dibutuhkan oleh DU/DI, pemerintah melaksanakan program keahlian dan keterampilan di SMK. Pendidikan kejuruan yang dilaksanakan oleh SMK mempunyai peran yang strategis dan diharapkan bukan hanya mampu menghasilkan tenaga kerja menengah tapi juga sebagai pengembangan pusat unggulan (centre of excellent) dan penguatan kemampuan SDM dan IPTEK nasional. Oleh karena itu, disain pendidikan keahlian di SMK harus relevan dan mengarah pada pendidikan keahlian yang dapat mencetak tenaga profesional yang memiliki kompetensi dan keterampilan guna memenuhi tuntutan DU/DI.

Ada beberapa alasan pentingnya relevansi pendidikan dengan DU/DI, dan pasar kerja antara lain adalah agar pendidikan dapat menghasilkan SDM unggul yang mampu mengelola sumber daya alam sesuai dengan kebutuhan dan tantangan yang dihadapi sekaligus mampu bersaing dengan negara lain. Lebih khusus lagi, pentingnya relevansi pendidikan dengan DU/DI, dan pasar kerja adalah SMK dapat menghasilkan SDM menengah unggul dalam bidang keahlian yang dibutuhkan oleh DU/DI atau dapat menciptakan pekerjaan sendiri yang kemudian dapat menyerap tenaga kerja yang ada.

Dari sisi SDM atau lulusan SMK, relevansi pendidikan SMK dengan DU/DI, dan pasar kerja dapat meningkatkan keterampilan lulusan SMK sesuai dengan kebutuhan DU/DI dan pasar kerja sehingga merubah mindset masyarakat dari pola konsumtif menjadi produktif. Selanjutnya, relevansi tersebut juga berdampak pada meningkatnya keterampilan lulusan menjadi pekerja-pekerja terampil. Menurut Hrmo et all (2016), pendidikan kejuruan memberikan kontribusi yang signifikan terhadap daya saing ekonomi dan kesejahteraan dalam ekonomi berbasis pengetahuan global sehingga perlu diperhatikan kebutuhan dengan dunia kerja dan kerjasama antar lembaga penyelenggara. Tantangan utama untuk pendidikan kejuruan adalah untuk memenuhi perubahan kebutuhan keterampilan individu dan dunia kerja sesuai dengan prinsip pembelajaran seumur hidup.

Berdasarkan uraian tersebut diatas, diperlukan sebuah kajian yang dapat menghasilkan rekomendasi kebijakan tentang bagaimana strategi penyelenggaraan SMK 
Perdana, Novrian Satria

OPTIMALISASI KESEIMBANGAN PASAR TENAGA KERJA LULUSAN SMK ...

REFLEKSI EDUKATIKA : Jurnal Ilmiah Kependidikan, Volume 9, Nomor 2, Juni 2019, hlm 172-181

terintegrasi yang dapat menghasilkan sumber daya manusia Indonesia yang memiliki daya saing internasional dan dapat memenuhi kebutuhan DUDI (mengurangi gap antara permintaan dan penawaran tenaga kerja lulusan SMK).

Saat ini telah banyak penelitian yang membahas terkait strategi pemenuhan tenaga kerja lulusan SMK. Pertama penelitian yang dilakukan Shodiq (2010) yang menyimpulkan bahwa a). minat Lulusan SMK bangunan untuk bekerja karena tergolong masih muda mereka belum merasa perlu untuk bekerja memenuhi kebutuhanya sendiri, sehingga mereka cenderung menunda untuk mencari pekerjaan, b). Pengalaman kerja lulusan SMK bangunan, pihak industri jasa konstruksi menganggap bahwa lulusan SMK bangunan kurang memiliki pengalaman lapangan, karena proses prakerin yang relatif singkat antara 1 sampai dengan 3 bulan, c). Koneksi orang dalam, perusahaan akan lebih mengutamakan faktor kerabat atau famili untuk mengisi kebutuhan tenaga kerjanya, walaupun kerabat atau famili tersebut tidak menguasai bidang keahliannya, dan d). Sikap dan kedisiplinan, faktor ini dinilai pihak industri jasa konstruksi secara langsung saat siswa SMK bangunan itu melakukan magang atau prakerin di perusahaan miliknya, dengan berpedoman pada faktor-faktor kompetensi, komitmen, dan disiplin.

Kedua, penelitian yang ditulis oleh Widodo (2016) menyimpulkan bahwa (1) Kebutuhan tenaga kerja di hotel bintang empat kota Yogyakarta posisi chef D3 berpengalaman 34 persen, SMK fresh graduate 29 persen, D3 fresh graduate 20 persen dan SMK berpengalaman 17 persen. Posisi daily worker D3 berpengalaman 35 persen, SMK fresh graduate 27 persen, D3 fresh graduate 23 persen dan SMK berpengalaman 15 persen. Posisi waiter D3 berpengalaman 32 persen, SMK berpengalaman 29 persen, SMK fresh graduate 22 persen dan D3 fresh graduate 17 persen; (2) Kompetensi tenaga kerja lulusan SMK fresh graduate jurusan Tata Boga untuk bekerja pada bidang food and beverage di hotel bintang empat kota Yogyakarta masih belum sesuai dengan kompetensi yang diharapkan. Nilai chef pada bidang tools and technology persentase 90\%. Nilai daily worker pada bidang work activity dan work value prosentase 88 persen dan 88 persen.
Nilai waiter pada bidang work activity persentase 95\%.

Ketiga, penelitian yang dilakukan oleh Indarti (2016) menunjukkan bahwa PDRB riil, PMA riil dan jumlah unit industri signifikan dan berpengaruh positif terhadap permintaan tenaga kerja, sedangkan upah riil signifikan dan berpengaruh negatif terhadap permintaan tenaga kerja. Untuk penawaran tenaga kerja, angkatan kerja dan upah riil signifikan dan berpengaruh positif terhadap penawaran tenaga kerja, sedangkan indeks pembangunan manusia signifikan dan berpengaruh negatif terhadap penawaran tenaga kerja.

Berdasarkan uraian di atas, maka tujuan dari penelitian ini antara lain:

1. Menganalisis permintaan (demand) DUDI terhadap kompetensi lulusan SMK dalam upaya mencapai keseimbangan pasar tenaga kerja

2. Menganalisis penyediaan (supply) lulusan SMK yang dibutuhkan DUDI dalam upaya mencapai keseimbangan pasar tenaga kerja.

\section{METODE PENELITIAN}

Dalam penelitian ini menggunakan pendekatan kualitatif dengan metode analisis primer melalui FGD bersama beberapa narasumber. Data primer mengenai strategi pemenuhan permintaan dan penawaran lulusan SMK diperoleh dari diskusi kepada kepala sekolah dan Bidang SMK Dinas Pendidikan Provinsi. Obyek penelitian ini adalah Provinsi Jawa Tengah tahun 2018, dengan sampel sekolah yang diambil berdasarkan tujuan tertentu (purposive sampling), yaitu berdasarkan capaian hasil UN dan perwakilan wilayah terdekat dengan Ibukota Provinsi. Sehingga sampel penelitian yang diundang untuk melakukan diskusi antara lain SMK Negeri Jawa Tengah,SMK Negeri 1 Salatiga, SMK Farmasi Nasional Surakarta, dan SMK Negeri 2 Pekalongan.

Untuk penajaman lebih lanjut serta untuk mendapatkan informasi yang lebih akurat mengenai kondisi permintaan dan penawaran lulusan SMK maka dilakukan Focus Group Discussion terhadap Dinas Pendidikan Provinsi Jawa Tengah, kepala SMK Negeri Jawa Tengah, SMK Negeri 1 Salatiga, SMK Farmasi Nasional Surakarta, dan SMK Negeri 2 Pekalongan, Politeknik Negeri Semarang, dan Industri yang bekerjasama dengan SMK sampel. Setelah data 
Perdana, Novrian Satria

OPTIMALISASI KESEIMBANGAN PASAR TENAGA KERJA LULUSAN SMK ...

REFLEKSI EDUKATIKA : Jurnal Ilmiah Kependidikan, Volume 9, Nomor 2, Juni 2019, hlm 172-181

semuanya terkumpul kemudian diolah dan dianalisis. Pengolahan dilakukan dengan cara mengelompokkan wilayah sampel, data jenis sekolah berdasarkan informasi yang diungkap (variabel) untuk selanjutnya dianalisis. Metode analisis yang digunakan dalam penelitian ini adalah deskriptif comparative (yakni mendeskripsikan obyek penelitian kemudian menghubungkan, membandingkan dan menarik kesimpulan).

\section{HASIL DAN PEMBAHASAN}

Salah satu masalah yang biasa muncul dalam penyerapan tenaga kerja adalah ketidakseimbangan akan permintaan tenaga kerja (demand for labor) dan penawaran tenaga kerja (supply of labor). Ketidakseimbangan tersebut berupa jumlah penawaran yang lebih besar dari permintaan terhadap tenaga kerja (excess supply of labor) atau lebih besarnya permintaan dibanding penawaran tenaga kerja (excess demand for labor). Diperlukan analisis mengenai pasar tenaga kerja untuk menentukan jumlah pekerja yang akan digunakan dalam kegiatan ekonomi. Pasar tenaga kerja tercipta karena adanya proses penempatan atau hubungan kerja yang meliputi permintaan dan penyediaan tenaga kerja. Berikut ini disampaikan uraian hasil survey ke Provinsi Jawa Tengah berdasarkan tujuan penelitian:

\section{Permintaan (demand) DUDI Terhadap Kompetensi Lulusan SMK}

Permintaan tenaga kerja menjelaskan berapa banyak perusahaan yang mempekerjakan tenaga kerja. Permintaan tenaga kerja ini bertujuan untuk membantu proses produksi. Jadi besarnya permintaan tenaga kerja tergantung dari output yang dihasilkan.

Berkaitan dengan permintaan tenaga kerja salahsatunya dapat dilihat pada data penyerapan tenaga kerja. Berdasarkan hasil Sakernas, angkatan kerja di Jawa Tengah tahun 2017 mencapai 18,01 juta. Tingkat partisipasi angkatan kerja penduduk Jawa Tengah tercatat sebesar 69,11 persen. Sedangkan tingkat pengangguran terbuka di Jawa Tengah sebesar 4,57 persen. Jumlah penduduk yang bekerja pada Agustus 2017 sebesar 17,19 juta orang. Sektor 1 (pertanian, kehutanan, perburuan dan perikanan) masih merupakan sektor yang paling banyak menyerap tenaga kerja, dengan menyerap sebanyak 4,32 juta orang (25,16 persen), sementara sektor 4 (listrik, gas, dan air) paling sedikit menyerap tenaga kerja, yaitu hanya menyerap 0,04 juta orang $(0,28$ persen $)$ pekerja. Proporsi terbesar pekerja pada Agustus 2017 masih didominasi oleh buruh/karyawan/pegawai sebesar 34,80 persen atau 5,75 juta orang. Sementara proporsi terkecil pekerja adalah pekerja berusaha dibantu buruh tetap/ buruh dibayar hanya sebesar 3,03 persen atau 0,50 juta orang.

Dalam kaitannya dengan revolusi industri 4.0, banyaknya pekerja yang terserap pada industri agro (sektor 1) di Provinsi Jawa Tengah tersebut searah dengan kebijakan Pemerintah yang akan memprioritaskan sektor tersebut untuk menuju revolusi industri 4.0 agar terjadi peningkatan produksi. Adapun sektor industri prioritas menuju revolusi industri 4.0 menurut Kemenperin (2017) meliputi: makanan dan minuman, kimia, tekstil dan pakaian jadi, otomotif dan elektronika. Dengan ditetapkannya kelima sektor prioritas tersebut, maka diperlukan peningkatan kualitas pekerja agar tidak terkena automatisasi akibat adanya revolusi industri 4.0. Data tersebut sejalan dengan informasi yang diperoleh melalui diskusi dengan sejumlah narasumber di daerah yang menyatakan bahwa industri di Provinsi Jawa Timur telah mengalami fase revolusi industri 4.0, dimana semua sudah mengarah ke digitalisasi. Peran-peran produksi yang selama ini dikerjakan melalui tenaga kerja, sudah mulai berkurang. Digantikan digitalisasi program. Dimana peran dalam industri sudah mulai beralih dengan konsentrasi ke arah digitalisasi. Digitalisasi ini membutuhkan sumber daya manusia yang lebih mengedepankan kerja otak ketimbang yang lain.

Capaian jumlah tenaga kerja yang terserap pada sektor prioritas revolusi industri 4.0 tersebut ternyata tidak diimbangi dengan kualitas pekerjanya. Berdasarkan data BPS Provinsi Jawa Tengah (2018), terdapat jumlah penduduk berumur 15 tahun ke atas yang termasuk angkatan kerja sejumlah 18.010.612 orang. Diantara sejumlah angkatan kerja tersebut memiliki pendidikan tertinggi paling banyak yaitu sekolah dasar sebanyak 5.327.438 jiwa, kemudian disusul oleh sekolah menengah pertama dan sekolah menengah atas dengan masing-masing sejumlah 3.348 .560 jiwa dan 2.107.292 jiwa. 


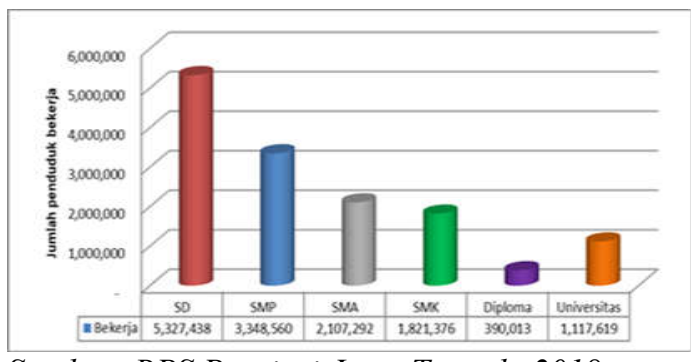

Sumber: BPS Provinsi Jawa Tengah, 2018

Gambar 5. Jumlah Penduduk Berumur $15 \mathrm{Th} \mathrm{Ke}$ Atas Menurut Pendidikan Tertinggi yang Ditamatkan di Provinsi Jawa Tengah

Berdasarkan data pada gambar 5 di atas, latar belakang pendidikan pekerja di Provinsi Jawa Tengah yang terbanyak adalah lulusan SD (38 persen). Sama halnya temuan di tingkat Nasional, capaian pendidikan pekerja yang berada pada tingkat $\mathrm{SD}$ / ke bawah dikhawatirkan akan menghambat produktifitas pekerjanya karena minimnya pengetahuan teknis yang diperoleh sebelum bekerja. Terkait capaian pendidikan pekerja, untuk SMK hanya mampu terserap sebesar 13 persen dari sejumlah pekerja. Selain rendahnya keterserapan lulusan SMK di Jawa Tengah, ternyata lulusan SMK (bersama SMA) menyumbang pengangguran terbuka yang terbanyak (sebesar 30 persen, sebesar 226.929 lulusan). Jika dihubungkan mengenai tujuan keberadaan SMK, maka diperlukan upaya revitalisasi SMK agar terjadi peningkatan daya serap ke industri.

Hasil ini sesuai dengan penelitian Indarti (2016), sehingga diperlukan upaya khusus untuk meningkatkan lulusan SMK. Adanya relevansi pendidikan SMK dengan DU/DI, dan pasar kerja dapat meningkatkan keterampilan lulusan SMK sesuai dengan kebutuhan DU/DI dan pasar kerja sehingga merubah mindset masyarakat dari pola konsumtif menjadi produktif. Selanjutnya, relevansi tersebut juga berdampak pada meningkatnya keterampilan lulusan menjadi pekerja-pekerja terampil. Oleh karena itu, usaha yang harus dilakukan adalah membangun dan memperkuat kerjasama antara SMK, DU/DI, pemerintah daerah, dan perguruan tinggi khususnya politeknik. Kerjasama tersebut meliputi pendidikan dan pelatihan SMK yang sesuai dengan bidang garapan industri dan potensi sumber daya alam atau kearifan lokal, serta kebutuhan masyarakat di masing-masing tempat SMK berada.

Sejalan dengan hasil di atas, berdasarkan hasil diskusi dengan DUDI saat verifikasi di daerah, kualifikasi tenaga kerja yang dibutuhkan DUDI skala menengah ke atas yang utama adalah telah memiliki sertifikat kompetensi, memiliki kemampuan IT dan bahasa asing, dan telah memiliki pengalaman bekerja pada bidang yang sama selama 1 tahun. Hal ini bertujuan agar tenaga kerja yang diterima sudah langsung bekerja tanpa harus dilatih berlama-lama yang tentunya dapat membebani anggaran DUDI.

\section{Penyediaan (supply) Tenaga Kerja Lulusan SMK yang yang Dibutuhkan DUDI}

Sekolah Menengah Kejuruan (SMK) merupakan pendidikan pada jenjang menengah yang mengutamakan pengembangan keterampilan siswa. Keterampilan yang dimiliki merupakan hasil dari pembelajaran di sekolah maupun di industri. Dunia industri berperan penting dalam proses pembelajaran di SMK, yaitu dengan bekerjasama dalam pelaksanaan praktik industri. Praktik industri bagi siswa SMK merupakan ajang menerapkan ilmu yang pernah diperoleh di bangku sekolah. Siswa juga akan mendapatkan ilmu baru di industri, karena mereka belajar pada kondisi nyata dengan suasana kerja yang sebenarnya.

Mengingat pentingnya keberadaan SMK pada abad ke-21, maka pengembangan SMK saat ini mulai bergerak dari orientasi pasar tenaga kerja lokal kepada pasar tenaga kerja ASEAN menyambut masyarakat ekonomi ASEAN (MEA), serta mempersiapkan para lulusan dengan pembekalan karakter kewirausahaan (entrepreneurship).

Pentingnya keberadaan SMK telah mendorong Pemerintah melakukan berbagai upaya untuk merevitalisasi SMK. Namun usaha tersebut belum sepenuhnya membuahkan hasil, yang mana salah satu indikatornya adalah masih rendahnya lulusan SMK. Berdasarkan data pekerja pada tahun 2017 di Provinsi Jawa Tengah dari sebanyak 17.186 .674 pekerja yang masuk pada angkatan kerja, lulusan SMK hanya memiliki sejumlah 1.821 .376 orang (sebesar $13 \%$ ) yang bekerja. Rendahnya jumlah angkatan kerja jenjang SMK ini salah satunya mengindikasikan rendahnya keterserapan lulusan SMK. Capaian angkatan kerja SMK tersebut 
Perdana, Novrian Satria

OPTIMALISASI KESEIMBANGAN PASAR TENAGA KERJA LULUSAN SMK ...

REFLEKSI EDUKATIKA : Jurnal Ilmiah Kependidikan, Volume 9, Nomor 2, Juni 2019, hlm 172-181

bertolak belakang dengan kondisi kemajuan SMK di Provinsi Jawa Tengah. Berdasarkan hasil diskusi dengan sejumlah narasumber, beberapa SMK di Provinsi Jawa Tengah telah mendapatkan status sekolah berstandar internasional dengan mendapatkan sertifikat dari International Standard Organization (ISO). Sekolah tersebut menggunakan dua bahasa dalam pembelajarannya, yakni Bahasa Indonesia dan Bahasa Inggris. Sekolah tersebut juga memiliki kerja sama dengan kalangan dunia usaha, baik di dalam negeri maupun di luar negeri. Sarana dan prasarana di sekolah itu juga telah memenuhi standar pelayanan minimal dan memiliki program-program unggulan.

Pada strategi peningkatan kualitas SDM Kejuruan dan sekaligus penguatan pendidikan kejuruan, pihak Dinas Pendidikan Provinsi telah membentuk Unit mobil keliling kejuruan yang terdiri dari berbagai jenis bidang keahlian. Mobil Keliling ini dikelola oleh Unit Pelayanan Teknis Pendidikan Pelatihan dan Pengembangan Kejuruan (UPT-PPPK) Dinas Pendidikan Provinsi Jawa Tengah yang diperuntukkan sebagai layanan pelatihan pada pendidikan kejuruan ke sekolah-sekolah yang membutuhkan. Peralatan praktik yang dibawa mobil keliling disesuaikan dengan permintaan sekolah, secara otomatis instruktur yang membimbing juga harus kompeten dibidang tersebut. Keberadaan mobil keliling di suatu sekolah sangat bergantung pada jumlah siswa dan tingkat kompetensi yang diharapkan. Adapun biaya operasional pelayanan praktik keliling semuanya ditanggung oleh Pemerintah Provinsi Jawa Tengah, peserta praktik maupun sekolah tidak dibebani biaya sedikitpun (gratis).

Salah satu contoh, adalah mobil keliling Broadcast. Mobil keliling ini ditujukan untuk memberikan layanan pengembangan SDM di bidang multimedia, broadcast radio dan televisi bagi peserta didik, tenaga pendidik dan kependidikan terutama jenjang SMK yang mempunyai bidang keahlian broadcast dan multimedia tetapi belum mempunyai peralatan broadcast dan multimedia. Mobil tersebut digunakan untuk praktikum kepenyiaran radio, televisi dan produksi program audio visual.

Berdasarkan hasil analisis permintaan dan penawaran tenaga kerja lulusan SMK pada dua Provinsi, berikut ini disimpulkan gambar titik keseimbangan tenaga kerja lulusan SMK. Titik keseimbangan yang tertera pada gambar 6 di bawah ini, Provinsi Jawa Tengah menunjukkan hasil yang fluktuatif. Pada tahun 2014 sebesar 88,76 persen kemudian menurun pada tahun 2015 menjadi 87,35 persen dan selanjutnya meningkat tajam menjadi 88,89 persen pada tahun 2016, menurun tipis pada tahun 2017 dan akhirnya meningkat menjadi 88,76 persen pada tahun 2018. Berdasarkan hasil FGD, hal ini salahsatunya disebabkan karena minimnya ketersediaan lapangan kerja yang sesuai dengan kompetensi keahlian yang ada pada SMK di Provinsi Jawa Tengah. Selain itu karena adanya tingginya standar pekerja yang dapat diterima oleh DUDI sehingga beberapa lulusan SMK tidak dapat langsung terserap oleh DUDI. Beberapa lulusan SMK yang tidak dapat terserap tersebut sebagian besar melanjutkan kursus kompetensi atau ke politeknik untuk dapat memperoleh pekerjaan yang dibutuhkan oleh DUDI.

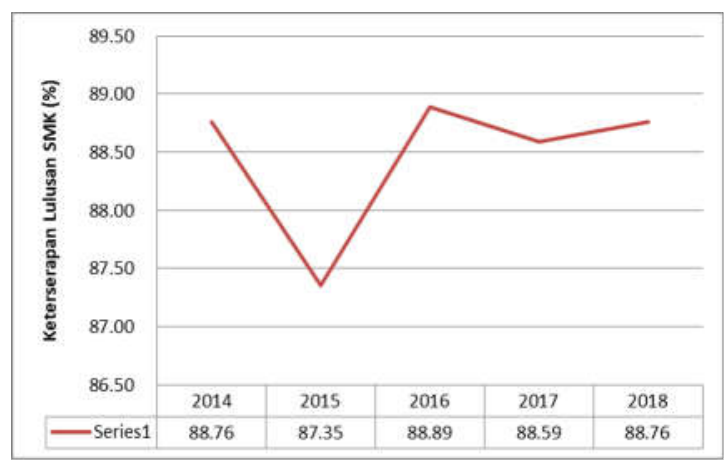

Sumber: BPS, 2019

Gambar 6. Keseimbangan Permintaan dan Penawaran Tenaga Kerja Lulusan SMK

Berdasarkan hasil diskusi dengan beberapa narasumber, dalam kaitannya dengan penyerapan lulusan SMK, DUDI lebih memilih lulusan SMK yang memiliki karakter disiplin, jujur, dan tekun. Dalam hal ini SMK telah berupaya meningkatkan kompetensi lulusan yang dihasilkan menyesuaikan kebutuhan DUDI, namun adanya keterbatasan kemampuan lulusan SMK karena minimnya sarana dan prasarana yang ada di sekolah dan keterbatasan kemampuan tenaga pendidik. Untuk mengatasi masalah ini SMK menjalin kerjasama dengan Politeknik dan lembaga kursus. Selanjutnya dalam upaya mempercepat penyerapan lulusan, sekolah menjalin jejaring alumni yang telah bekerja, bekerjasama dengan SMK lain yang 
Perdana, Novrian Satria

OPTIMALISASI KESEIMBANGAN PASAR TENAGA KERJA LULUSAN SMK ...

REFLEKSI EDUKATIKA : Jurnal Ilmiah Kependidikan, Volume 9, Nomor 2, Juni 2019, hlm 172-181

lebih berkualitas, bekerjasama dengan DUDI dan Politeknik.

Selain pola kerjasama, ada juga upaya personal untuk lulusan SMK yang perlu diperbaiki yaitu terkait dengan penggunaan bahasa internasional, yangmana dalam hal ini bahasa Inggris. Menurut hasil FGD bersama narasumber, sejumlah DUDI menginginkan lulusan yang dapat menguasai bahasa. Salahsatu upaya dalam menguasai bahasa adalah dengan menggunakan media debat bahasa. Menurut penelitian yang dilakukan oleh Rokhayani, dkk (2015), keberhasilan peningkatan Speaking bahasa Inggris yang dimiliki mahasiswa adalah melalui debat bahasa. Keefektifan English Debate sebagai teknik pembelajaran dilihat dari hasil observasi pembelajaran. English Debate sangat tepat dan efektif digunakan sebagai teknik pembelajaran karena memberikan kesempataan bagi mahasiswa untuk mengekspresikan ide yang dimiliki ketika berdebat. Ini juga berdampak pada kemampuan Speaking mahasiswa dalam menyampaikan ungkapan-ungkapan bahasa Inggris menjadi lebih bagus.

Upaya lainnya dalam peningkatan kualitas lulusan melalui peningkatan kualitas pembelajaran adalah melalui penggunaan alat peraga. Berdasarkan hasil penelitian yang dilakukan oleh Suyitno (2015), penggunaan alat peraga yang disesuaikan dengan karakteristik lingkungan siswa dan penggunaan metode eksperimen ternyata dapat menarik minat belajar siswa, sehingga hasil belajar siswa bisa maksimal terbukti nilai ketuntasan klasikal tes formatif meningkat secara signifikan. Dengan alat peraga dan metode yang sesuai siswa akan senang dalam mengikuti proses pembelajaran, karena belajar sambil bermain siswa akan lebih tertarik.

Dalam penyelenggaraan pendidikan vokasi, terdapat tiga jenis satuan pendidikan di Kementerian Pendidikan dan Kebudayaan yang terlibat, yaitu SMK, LKP, dan SMALB. Ketiga jenis satuan pendidikan ini mempunyai proses penyelenggaraan pendidikan yang berbeda. SMK dan SMALB berada di pendidikan formal, sedangkan LKP berada di pendidikan nonformal. Selama ini, ketiga pendidikan ini berdiri secara sendiri-sendiri dalam menjalankan proses pendidikan. Skema integrasi antar lembaga ini juga terjadi di Negara lain. Menurut Vroonhof, et all (2017), beberapa reformasi pendidikan kejuruan sedang berlangsung di Eropa untuk memperkenalkan lebih banyak model pemagangan atau untuk mengimplementasikan bentuk lain dari pembelajaran berbasis kerja. Adanya sistem pemagangan sering kali menjadi target implisit atau eksplisit dari inisiatif, menunjukkan kualitas lulusan yang tinggi dengan keterlibatan dunia bisnis melalui pembelajaran berbasis sekolah dengan praktik di perusahaan.

\section{SIMPULAN DAN Saran}

\section{A. Simpulan}

Berdasarkan hasil analisis, maka kesimpulan dari kajian ini antara lain:

1. Kualifikasi tenaga kerja yang dibutuhkan DUDI skala menengah ke atas yang utama adalah telah memiliki sertifikat kompetensi, memiliki kemampuan IT dan bahasa asing, dan telah memiliki pengalaman bekerja pada bidang yang sama selama 1 tahun,

2. Kompetensi lulusan SMK yang dihasilkan telah diupayakan menyesuaikan kebutuhan DUDI, namun adanya keterbatasan kemampuan lulusan SMK karena minimnya sarana dan prasarana yang ada di sekolah dan keterbatasan kemampuan tenaga pendidik. Untuk mengatasi masalah ini SMK menjalin kerjasama dengan Politeknik dan lembaga kursus.

\section{B. Saran}

Berdasarkan hasil analisis dan kesimpulan, maka diberikan saran sebagai berikut:

1. Menerapkan model pembelajaran yang terintegrasi dengan kebutuhan DUDI;

2. Diperlukan MoU antara Kemendikbud, Kemenakertrans dan Kemenperin dalam menyusun skema penyiapan tenaga kerja vokasional yang dibutuhkan industri, termasuk kerjasama penyediaan sarana dan prasarana pendidikan serta tenaga pendidik yang kompeten;

3. Perlunya perubahan pola pikir bahwa lulusan vokasional tidak hanya berfokus pada bekerja tetapi menciptakan lapangan kerja. 
Perdana, Novrian Satria

OPTIMALISASI KESEIMBANGAN PASAR TENAGA KERJA LULUSAN SMK ...

REFLEKSI EDUKATIKA : Jurnal Ilmiah Kependidikan, Volume 9, Nomor 2, Juni 2019, hlm 172-181

\section{DAFTAR PUSTAKA}

Badan Pusat Statistik. 2018. Angkatan Kerja Indonesia Menurut Tingkat Pendidikan .

Badan Pusat Statistik Provinsi Jawa Tengah, 2018. Provinsi Jawa Tengah Dalam Angka Tahun 2018.

Direktorat PSMK, 2017. Grafik Automatisasi Akibat Perkembangan Teknologi. Kemendikbud RI.

Hrmo, Roman, et all., 2016. Improving the Quality of Technical and Vocational Education in Slovakia for European Labour Market Needs. iJEP 6 (2).

Indarti, Titis Wahyu, 2016. Analisis FaktorFaktor Yang Memengaruhi Permintaan Dan Penawaran Tenaga Kerja Sektor Industri Di Pulau Jawa Tahun 2004-2015. Tesis. Bogor: IPB.

Rokhayani, dkk. 2015. Peningkatan Ketrampilan Berbicara (Speaking) Mahasiswa Melalui Teknik English Debate. Universitas Muria Kudus. Refleksi Edukatika: Jurnal Ilmiah Kependidikan, 5 (1).
Shodiq, Fajar Kurniawan, 2010. Analisis Ketersediaan Dan Kebutuhan Tenaga Kerja Lulusan SMK Bangunan Di Surakarta Pada Sektor Industri Jasa Konstruksi. Skripsi. Surakarta: Universitas Sebelas Maret.

Suyitno, 2015. Upaya Meningkatkan Kualitas Hasil Pembelajaran Siswa Terhadap Materi Pesawat Sederhana Kelas V Sd Negeri Ngawen. Refleksi Edukatika: Jurnal Ilmiah Kependidikan, 5 (1).

The McKinsey Global Institute, 2017. A Future That Works: Automation, Employment, And Productivity. Executive Summary.

Vroonhof, Paul, Et All., 2017. Business Cooperating With Vocational Education And Training Providers For Quality Skills And Attractive Futures. European Commission: Directorate-General For Employment, Social Affairs And Inclusion.

Widodo, Gunawan, 2016. Analisis Kebutuhan Tenaga Kerja Lulusan SMK Fresh Graduate Jurusan Tata Boga Pada Bidang Food And Beverage Di Hotel Bintang Empat Kota Yogyakarta. Universitas Negeri Yogyakarta.

World Economic Forum, 2018. The Global Competitiveness Report 2018. 